\title{
The survey on the infection control of noncritical instruments used in dental treatment
}

\author{
Jae Hyun Kim, Jin-Han Lee* \\ Department of Prosthodontics, College of Dentistry, Wonkwang University, Iksan, Republic of Korea
}

Purpose: The aims of this study were to evaluate the dentist's awareness and the actual status of infection control of noncritical dental instruments. Materials and Methods: 40 dental clinics in Daejeon, South Chungcheong, North Chungcheong and North Jeolla provinces were surveyed. The questionnaire was delivered to the dentists belonging to those clinics, and the awareness and the practice of infection control were examined. The microbial contamination on the surface of five noncritical instruments (impression gun, light curing unit, 3-way syringe, shade guide, and dental floss dispenser) used by them was measured with an ATP luminometer. Correlation analysis between the awareness and the actual state of infection control was conducted. Results: Awareness and frequency of infection control was highest in the 3-way syringe. Surface disinfection using disinfectant was most frequent in all instruments. 3-way syringes and shade guides were less contaminated than impression guns, light curing units, and dental floss dispensers. Conclusion: 3-way syringes had a significant correlation between user awareness of infection control and surface contamination, and the higher awareness, the lower the contamination measurement was shown. (J Dent Rehabil Appl Sci 2019;35(1):27-36)

Key words: infection control; dental instrument; noncritical instrument; surface contamination

\begin{abstract}
서론
의료 기관에서 시행하는 여러 가지 시술이나 치료 과 정에서 진료 종사자와 환자는 모두 감염에 노출된다. 과 거에 비해 의료 기관에서 시행하는 침습적 검사와 수기 가 증가하였고, 각종 항생제에 대한 내성균도 증가하고 있기 때문에 의료 관련 감염의 예방은 중요한 문제로 대 두되고 있다. ${ }^{1}$ 의료와 관련된 감염 관리는 치과 진료실 에서 더욱 중요하다. 치과에 내원한 환자와 근무하고 있 는 진료 종사자는 모두 진료실 내에서 다양한 병원성 미 생물에 노출되어 있다. 이러한 병원성 미생물은 환자 혈 액과 타액의 직접 접촉과 오염된 기구나 장비를 통한 간 접 접촉을 통해 전파될 수 있다. 환자의 기침, 재채기, 대

*Correspondence to: Jin-Han Lee Professor, Department of Prosthodontics, College of Dentistry, Wonkwang University, 77 Doonsan-ro, Seo-gu, Daejeon, 35233, Republic of Korea Tel: +82-42-366-1150, Fax: +82-42-366-1115, E-mail: dentist@empas.com Received: January 14, 2019/Last Revision: January 18, 2019/Accepted: March 8, 2019
\end{abstract}

화를 통해 공기 중에 떠 있는 병원성 미생물은 결막, 비점 막, 구강점막으로 접촉하거나 흡입을 통한 다양한 경로 로 전파될 수 있다. ${ }^{2}$ 특히 치과 치료는 출혈이 동반되는 치료의 빈도가 높기 때문에 환자의 혈액에 의해 직접적으 로 감염에 노출될 수 있고, 치과 치료에 사용되는 고속 회 전기구나 초음파 치석제거기의 사용 중 발생하는 에어로 졸 및 분진에 의해서 간접적으로 감염에 노출될 수 있다. 따라서 치과진료실에서는 다양한 병원체가 직간접적으 로 전달되어 환자와 치과 진료 종사자, 환자와 환자 사이 에 교차 감염을 유발할 수 있다. ${ }^{3}$

대한민국의 고령화는 빠르게 진행되고 있다. 통계청 의 ‘2018 고령자 통계'에 따르면 65세 이상 고령자 비중 은 $14.3 \%$ 로 증가추세에 있으며, 2025 년에는 $20 \%$ 에 이

Copyright@ 2019 The Korean Academy of Stomatognathic Function and Occlusion. (c) It is identical to Creative Commons Non-Commercial License. 
를 것으로 예상되고 있다. ${ }^{4}$ 인구의 고령화로 인해 감염 에 취약한 환자가 지속적으로 증가함에 따라 치과 기구 의 감염 관리의 중요성이 더욱 부각되고 있다. ${ }^{5}$ 또한 환자 뿐만 아니라 치과 진료 종사자들은 타액이나 혈액과 밀 접한 접촉을 하고 있기 때문에 감염에 대한 위험이 다른 직업군보다 높다. ${ }^{6}$ 따라서 감염 관리는 환자와 치과 진료 종사자 모두에게 중요한 문제이기 때문에, 치과 진료 종 사자들은 적절한 감염 관리를 통해 치과 진료실에서의 의료 관련 감염 전파를 예방할 수 있도록 노력해야 한다.

치과 치료에 사용하는 기구는 잠재적 감염 전파 위험 도에 따라 고위험 기구, 준위험 기구, 비위험 기구로 분류 할 수 있다. 고위험 기구는 연조직과 경조직을 관통하거 나 인체조직에 직접 삽입하는 기구, 준위험 기구는 연조 직과 경조직을 관통하지 않지만 점막이나 손상된 피부를 접촉하는 기구, 비위험 기구는 손상받지 않은 건강한 피 부에 접촉하는 기구이다. ${ }^{7}$ 1996년 미국 치과의사협회에 서 발표한 감염 관리 권장사항에 의하면 고위험 기구와 준위험 기구는 멸균을 시행해야 하며 비위험 기구의 경 우 소독을 시행하여야 한다. ${ }^{8}$ 또한 2003년 미국 질병 통 제 및 예방 센터의 지침은 비위험 기구에서 세척 및 소독, 표면 덮개(barrier film)의 부착을 권장하였다. ${ }^{9}$ 비록 치과 치료에 사용되는 비위험 기구는 환자에게 감염을 직접적 으로 전파할 가능성은 낮지만, 치과 치료과정에서 여러 기구가 다양하게 사용되기 때문에 환자의 체액이 묻은 술자의 장갑을 통해서 감염이 다른 기구로 간접적으로 전파될 가능성은 높다. ${ }^{9}$ 감염 전파 위험도가 낮은 기구일 수록 치과의사의 감염 관리 필요성에 관한 인지도가 낮 아지는 경향이 있기 때문에, 고위험 기구나 준위험 기구 와는 달리 상대적으로 안전하다고 여겨지는 비위험 기구 의 감염 관리가 임상에서 실제로 적절하게 이루어지고 있 는지는 의문의 여지가 있다. ${ }^{10}$ 기존의 많은 연구에서 치과 기구들의 감염 관리에 관한 조사가 시행되었으나 비위 험 기구를 대상으로 한 연구는 그 수가 많지 않으며, 연 구 대상 중 비위험 기구가 포함된 연구들은 설문 조사를 통해 감염 관리에 대한 치과 진료 종사자들 인식만을 연 구한 경우가 많았다. ${ }^{11,12}$ 이에 본 연구에서는 치과 치료에 사용되는 비위험 기구 중, 의료 기관에서 공통적으로 사 용하여 비교가 용이한 인상용 건(impression gun), 광중 합기, 3-way syringe, 색조 견본, 치실통을 대상으로 감염 관리의 필요성에 관한 치과의사의 인지도를 설문 조사하 고, 기구의 표면 오염도를 직접 측정함으로써 비위험 기 구의 감염 관리 실태를 조사하고자 하였다.

\section{연구 대상 및 방법}

40 개의 치과 병, 의원을 연구 대상으로 하였고, 연구 대 상의 지역적 분포는 대전광역시, 충청남도, 충청북도, 전 라북도였다. 감염 관리에 대한 치과의사의 인지도와 실천 정도에 관해서 설문 조사를 시행하였고, 치과의사가 치과 치료에 사용하는 인상용 건, 광중합기, 3-way syringe, 색 조 견본, 치실통의 표면 오염도를 각각 측정하였다.

\section{설문 조사}

치과의사를 대상으로 치과 치료에 사용하는 비위험 기 구의 감염 관리에 대한 인지도를 파악하기 위해, 선행 논 문을 참고하여 작성한 설문지를 이용하여 한 명의 실험 자에 의해 면접 응답으로 설문 조사를 시행하였다. ${ }^{13}$ 질 문은 응답자의 일반적 특성, 비위험 기구에 대한 감염 관 리의 인식, 감염 관리 빈도, 감염 관리에 사용하는 방법, 감염 관리를 시행하지 않는 경우의 이유에 관한 항목으 로 구성되었다.

일반적 특성은 응답자의 성별, 연령, 근무 경력에 관한 항목으로 이루어졌다. 비위험 기구의 감염 관리 필요성 의 인식을 묻는 항목은 응답자가 해당 기구의 감염 관리 필요성에 대해 인식하고 있는 정도이다. 각 항목은 "나 는 이 기구는 철저한 감염 관리가 필요하다고 생각한다." 라는 질문에 대하여 5단계의 Likert 척도를 이용하여 "전 혀 그렇지 않다”(1점), “그렇지 않다”(2점), “보통이다" (3점), “그렇다"(4점), “매우 그렇다"(5점)로 점수화하여 점수가 높을수록 인지도가 높은 것으로 하였다. ${ }^{14}$ 비위 험 기구의 감염 관리 빈도를 묻는 항목은 응답자가 해당 기구의 감염 관리를 시행하는 빈도였다. 각 항목은 "나 의 기구 감염 관리 빈도는?"라는 질문에 대하여 5 단계의 Likert 척도를 이용하여 “시행하지 않는다”(1점), “주 1 번”(2점), “하루 1번”(3점), “하루 1번 이상”(4점), “매 사 용 시마다”(5점)로 점수화하여 점수가 높을수록 감염 관 리 빈도가 높은 것으로 하였다. 비위험 기구의 감염 관리 에 사용하는 방법에 관한 항목은 소독이 이루어지고 있 는 방식에 대해 알아보기 위한 것으로, 응답자에게 각 기 구별로 시행하고 있는 소독 방법 모두를 다중 응답식으 로 답변하도록 하였다. 감염 관리를 하지 않는 이유에 관 한 항목은 감염 관리 실천에 장애가 되는 요인을 알아보 기 위한 문항으로, 응답자가 가장 동의하는 두 가지 이유 를 선택하여 다중 응답식으로 답변하도록 하였다. 


\section{표면 오염도 측정}

인상용 건, 광중합기, 3-way syringe, 색조 견본은 동일 한 부위에서 동일한 면적의 표면 오염도를 측정하기 위 하여 투명 플라스틱 필름을 판형(template)으로 하여 표 면에 동일하게 적용하였다. 측정부위는 인상용 건에서 방아쇠(trigger)의 전방부위 $1.6 \times 6.25 \mathrm{~cm}$, 광중합기에 서 손잡이의 작동 버튼을 포함한 부위 $2 \times 5 \mathrm{~cm}, 3$-way syringe에서 손잡이의 전방부위 $2 \times 5 \mathrm{~cm}$, 색조 견본의 좌측 중단부위 $5 \times 2 \mathrm{~cm}$, 치실통에서 술자의 손가락이 접촉하는 상단면부위 $3 \times 3 \mathrm{~cm}$ 로 하였다(Fig. 1).

각각의 측정 부위를 Ultrasnap ${ }^{\mathrm{TM}}$ ATP swab (Hygiena LLC, Camarillo, USA)으로 20 초간 문질러서 검체를 채취하고 아데노신 3인산(ATP) 측정기(SystemSURE

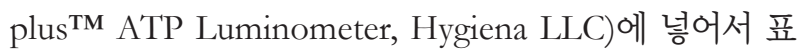
본의 표면 ATP를 측정하였다(Fig. 2). 넓은 평활면을 측 정할 수 있는 인상용 건, 광중합기, 3-way syringe, 색조 견본은 $10 \mathrm{~cm}^{2}$ 의 면적을 동일하게 측정하였고, 치실통은 $9 \mathrm{~cm}^{2}$ 의 동일한 면적을 측정하였다. 의료 기관 마다 검체 의 채취와 측정은 동일한 실험자에 의해서 진행되었다. 측정된 RLU (relative light unit)값은 측정 면적으로 나누 어 단위 면적당 RLU 값을 산출하였다.
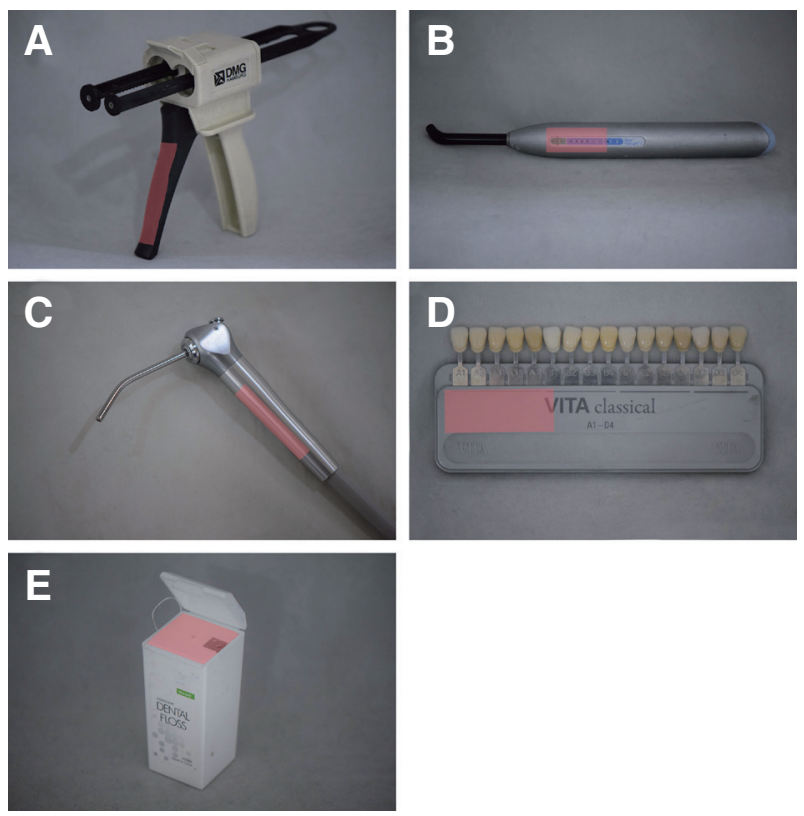

Fig. 1. Dental instruments for survey of infection control. (A) Impression gun, (B) Light curing unit, (C) 3-way syringe, (D) Shade guide, (E) Floss silk dispenser.

\section{통계 분석}

비위험 기구의 감염 관리에 사용하는 방법과 감염 관리 를 시행하지 않는 경우의 이유에 관한 문항은 각각 빈도 분석을 시행하였고, 수집된 자료는 통계프로그램(SPSS 24.0 for Windows, SPSS Inc., Chicago, USA)을 이용하 여 분석하였다. 치과 치료에 사용하는 기구별 오염도 수 준에 차이가 있는지 파악하기 위해 Kruskal-Wallis 검정 을 시행하였고, Bonferroni's method를 이용하여 집단 간 쌍대비교(Pair-wise comparison) 사후분석을 실시하 였다 $(\alpha=.05)$. 비위험 기구의 감염 관리 필요성의 인식 및 치과 비위험 기구의 감염 관리 빈도와 오염도 간 상관관 계를 파악하기 위해 Spearman 상관 계수를 이용하였다.

\section{결과}

연구대상자인 치과의사 총 40명 중 남성 36명 $(90 \%)$, 여성 4명 $(10 \%)$ 으로 남성이 여성보다 많았다. 연령대는 30 대가 19 명 $(47.5 \%)$ 으로 가장 많았으며, 20대가 8명 $(20 \%), 50$ 대가 6명(15\%), 40대가 3명(7.5\%), 60대가 3명 $(7.5 \%), 70$ 대가 1 명 $(2.5 \%)$ 순으로 나타났다. 근무 경력은 6 - 10년 16명(40\%), 5년 이하 9명(22.5\%), 26 - 30년 4명

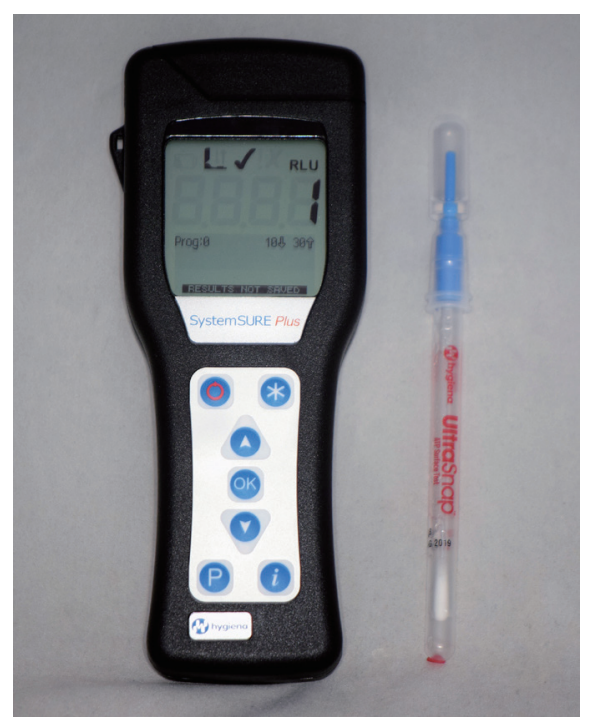

Fig. 2. Measurement devices for microbial contamination (Left: SystemSURE plus ${ }^{\text {TM }}$ ATP Luminometer, Right: Ultrasnap ${ }^{\text {TM }}$ ATP swab). 
(10\%), 11 - 15년 3명(7.5\%), 16 - 20년 3명(7.5\%), 31년 이상 3명 $(7.5 \%), 21$ - 25년 2명 $(5 \%)$ 순으로 나타났다. 연 구 대상자의 일반적 특성 중 어떠한 항목도 감염 관리의 필요성에 대한 인지도, 감염 관리 시행 빈도 및 기구 오염 도 측정값과 유의한 상관관계를 나타내지 않았다.

연구대상자들이 사용하는 감염 관리 방법에 관한 설문 결과는 다음과 같았다. 응답자들은 조사 대상인 5 개 기 구에 대해 질문에 제시된 감염 관리 방법 6가지(세척, 고 압증기멸균, 에틸렌 옥사이드 가스(EO gas) 멸균, 소독 액을 사용한 표면 소독, 표면 덮개 사용, 기타)중 현재 치 과에서 시행하는 방법을 각 기구별로 다중 응답식으로 응답하였다(Fig. 3).

감염 관리 시행 비율은 총 40 명의 응답 중, 해당 방법을 이용하여 해당 기구의 감염 관리를 시행하고 있다고 응 답한 수의 비율을 나타냈다. 모든 기구에서 '소독액을 사 용한 표면 소독’이 가장 높은 시행비율을 나타냈다. 인상 용 건, 광중합기, 색조 견본, 치실통에서 ‘세척'이 두 번째 로 높은 비율을 나타냈다. 3-way syringe에서는 '고압증 기멸균'이 $17.5 \%$ 로 두 번째로 높은 비율을 나타냈다. 기 타 의견을 자기 기입으로 응답한 사람은 없었다.

감염 관리를 시행하지 않는 이유에 관한 설문 결과는 다음과 같았다. 응답자들은 “감염 관리가 잘 시행되지 않는다면 그 이유는 무엇이라고 생각하십니까?”라는 문 항에 대해서 가장 동의하는 이유 2 가지를 다중 응답식으
로 응답하였다. 연구 대상자 40 명이 2개씩 답변한 80 개 의 응답 가운데 ‘필요성을 느끼지 못함’이 23개(전체 응 답자의 $57.5 \%$ )로 가장 높았으며, '과도한 업무량'이 22 개(전체 응답자의 $55 \%$ ), '기구 물품 부족'과 '기타'가 8개 (전체 응답자의 $20 \%$ ), '감염 관리 물품 부족'과 '경제적인 이유'가 7개(전체 응답자의 $17.5 \%$ ), '기구 손상에 대한 우 려'가 5 개(전체 응답자의 $12.5 \%$ ) 순으로 나타났다. 기타 의견으로는 '감염 관리 교육이 부족해서', '실천력 부족', ‘병력 검사 후 감염성 질환자만 따로 관리한다' 등이 있었 다.

치과의사 40 명이 치과 치료에 직접 사용하고 있는 5 종 의 비위험 기구에서 채취된 검체로 표면 오염도를 검사 하였다. 각각의 측정값은 측정 면적으로 나누어 계산된 단위 면적당 RLU 값을 통계적으로 분석하였다. 비교 분 석의 공통 가정인 정규성 검정을 시행하였으며, 각 군의 Shapiro-Wilk test결과 3-way syringe를 제외한 4개 집단 의 $P$ 값이 모두 유의수준 $(\alpha=.05)$ 이하로 정규성의 조건 을 만족하지 못하였다. 이에 각 기구 간 표면 오염도 측 정값이 유의한 차이가 있는지 알아보기 위해 KruskalWallis 검정을 실시하여 집단 간 비교 분석을 시행하였다. 검정 결과 유의수준 $5 \%$ 기준에서 집단 간 차이가 있는 것으로 나타났다 $(P=0.000)$. 각 기구별 측정값의 중간값 및 사분위 범위를 나타낸 박스플롯은 다음과 같다(Fig. 4).

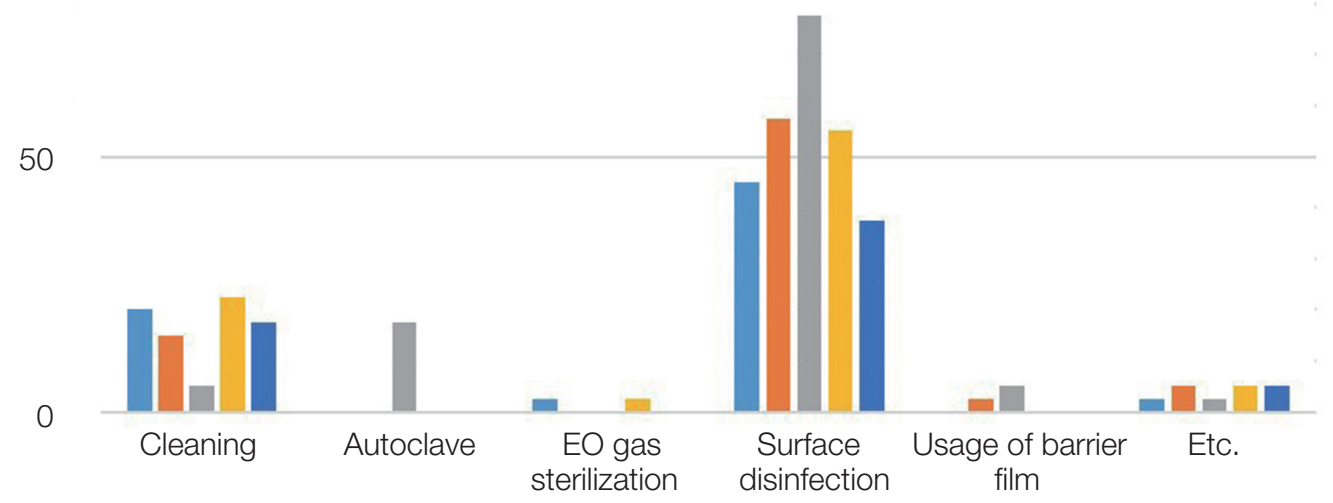

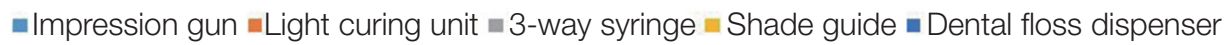

Fig. 3. Responses about infection control methods. 


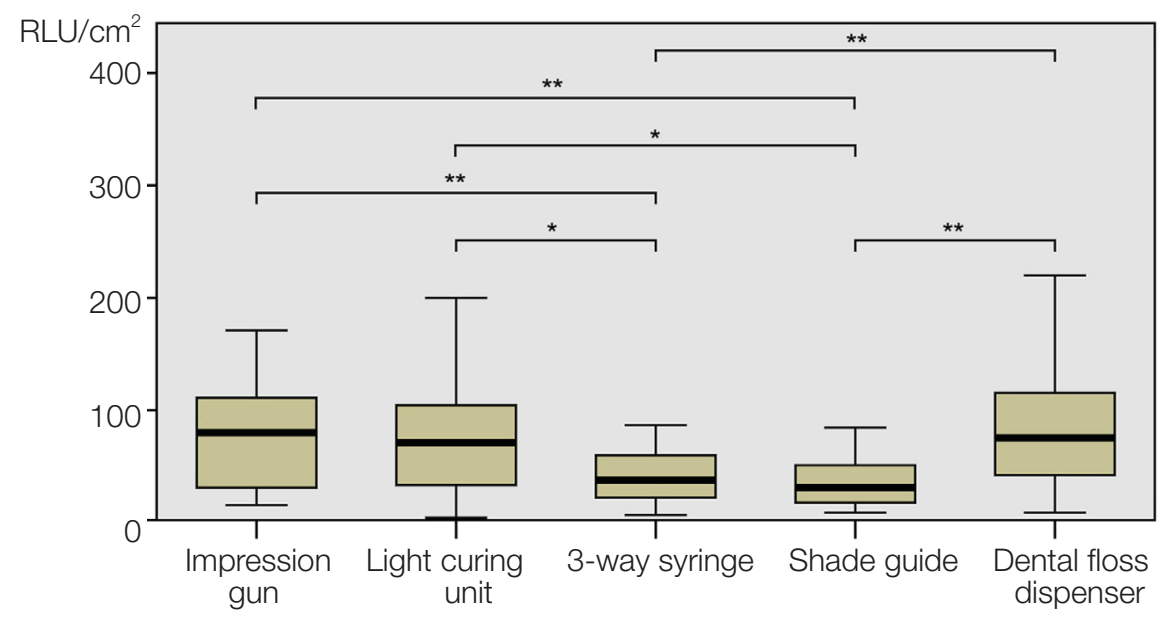

Fig. 4. Boxplot with median and inter quartile range of surface contamination $\left(\mathrm{RLU} / \mathrm{cm}^{2}\right) .{ }^{*} P<0.05,{ }^{* *} P<0.01$.

표면 오염도 측정값 간의 차이가 통계적으로 유의한 지 확인하기 위해 Bonferroni method를 이용하여 집단 간 쌍대비교(pairwise comparison) 사후분석을 실시하였 다 $(\alpha=.05)$. 사후분석 결과 3-way syringe, 색조 견본과 나머지 3개의 기구(인상용 건, 광중합기, 치실통) 사이에 서 통계적으로 유의한 차이가 있는 것으로 나타났다 $(P<$ 0.05). 3-way syringe 및 색조 견본 간에는 통계적 차이가 없는 것으로 나타났고, 나머지 3종의 기구 간에도 통계적 차이는 없는 것으로 나타났다(Fig. 4).

연구대상자들의 감염 관리에 대한 인식에 관한 문항에 대한 응답을 Likert 5 점 척도를 이용하여 점수화하였다. 감염 관리 인식에 대한 응답자들의 점수 평균은 3-way syringe (3.98), 광중합기(3.08), 색조 견본(2.70), 인상용 건(2.48), 치실통(2.40) 순으로 높았다. 감염 관리에 대한
인식과 표면 오염도 측정값과의 상관관계를 분석하기 위 해 Spearman 상관관계분석을 사용하였다. 3-way syringe 에서 통계적으로 유의한 상관관계가 존재하였으며, 상관 계수는 $-0.333(P<0.05)$ 이었다(Table 1).

연구대상자들의 감염 관리 빈도에 관한 문항에 대한 응답을 Likert 5점 척도를 이용하여 점수화하였다. 감염 관리 빈도에 대한 응답자들의 점수 평균은 3-way syringe (3.03), 색조 견본(2.45), 광중합기(2.33), 치실통(1.55), 인 상용 건(1.45) 순으로 높았다. 감염 관리 시행 빈도와 기 구 오염도 측정값과의 상관관계를 분석하기 위해 Spearman 상관관계분석을 사용하였다. 3-way syringe에서 통 계적으로 유의한 상관관계가 존재하였으며, 상관계수는 -0.660 ( $P<0.01)$ 이었다(Table 2).

Table 1. Spearman's co-relation co-efficient between the answers about infection control cognition and the surface contamination $\left(\mathrm{RLU} / \mathrm{cm}^{2}\right)$

\begin{tabular}{lccccc}
\hline \multirow{2}{*}{$\begin{array}{l}\text { Cognition of } \\
\text { infection control }\end{array}$} & Impression gun & Light curing unit & 3-way syringe & Shade guide & Dental floss dispenser \\
\hline Impression gun & -0.022 & 0.047 & 0.182 & 0.045 & 0.142 \\
Light curing unit & -0.045 & 0.140 & 0.298 & -0.137 & -0.045 \\
3-way syringe & -0.147 & -0.027 & $-0.333 *$ & 0.158 & -0.038 \\
Shade guide & -0.036 & -0.057 & 0.023 & 0.108 & 0.000 \\
Dental floss dispenser & -0.137 & 0.122 & 0.202 & 0.259 & 0.071 \\
\hline
\end{tabular}

* Correlation was significant at the 0.05 level. 
Table 2. Spearman's co-relation co-efficient between the answers about infection control frequencies and the surface contamination $\left(\mathrm{RLU} / \mathrm{cm}^{2}\right)$

\begin{tabular}{lccccc}
\hline \multirow{2}{*}{$\begin{array}{l}\text { Frequencies of } \\
\text { infection control }\end{array}$} & Impression gun & Light curing unit & 3-way syringe & Shade guide & Dental floss dispenser \\
\hline Impression gun & -0.098 & -0.004 & 0.034 & 0.010 & 0.173 \\
Light curing unit & 0.081 & 0.122 & 0.102 & -0.218 & 0.219 \\
3-way syringe & -0.259 & -0.206 & $-0.660^{* *}$ & -0.069 & -0.201 \\
Shade guide & -0.012 & -0.031 & -0.077 & 0.012 & -0.051 \\
Dental floss dispenser & 0.034 & 0.008 & 0.083 & -0.148 & 0.118 \\
\hline
\end{tabular}

** Correlation was significant at the 0.01 level.

\section{고찰}

우리나라 인구의 고령화가 빠르게 진행되고 있으며, 각종 항생제에 대한 내성균의 증가 등으로 인해 병원에 서의 감염 관리의 중요성은 점차 강조되고 있다. 1970년 대 이전의 감염 관리는 단지 감염성 환자의 취급에만 집 중되어 있었다. 그러나 1970년대 초반에 본격적으로 보 고되기 시작한 B형 간염 바이러스와 1980년대 초반에 발견된 인간면역결핍 바이러스로 인해 모든 환자에 대 한 감염 관리의 필요성이 대두되었다. ${ }^{15,16} 1980$ 년대의 미 국 질병관리본부 지침 및 권고사항에 근간을 두고 작성 된 2003년의 감염 관리 지침은 모든 환자의 체액과 혈액 을 잠재적인 감염원으로 간주하고 감염 관리를 시행하는 것이다. ${ }^{16,17}$ 이에 따라 환자 진료에 사용하는 모든 기자재 에 대한 감염 관리의 필요성이 제시되었다. 대한치과의사 협회에서도 치과에서 사용하는 기자재의 소독과 멸균법 에 따른 분류법과 감염 관리 방법에 대한 지침을 발표하 였다. ${ }^{18}$ 대한치과의사협회의 지침에 따르면, 치과 기자재 는 잠재적 감염병 전파 위험도에 따라 위험한 기구, 덜 위 험한 기구, 위험하지 않은 기구로 분류되며, 위험도에 따 른 분류와 무관하게 치과 치료에 사용되는 모든 기구는 각 기구에 맞는 방식으로 감염 관리를 시행하여야 한다.

본 연구의 연구 대상인 5 종의 기구는 비위험 기구로 분 류된다. 비위험 기구는 환자의 연조직 및 경조직을 관통 하거나 점막에 접촉하지 않고, 환자의 건강한 피부에 접 촉하거나 혹은 환자와 간접적으로 접촉하는 기구이다. 일반적으로 비위험 기구에 의한 감염 전파의 위험은 타 기구들에 비해 낮다. 그러나 환자의 점막에 접촉하지 않 는 기자재들도 진료 도중 환자 구강으로부터 직접 체액 이나 혈액이 튀어서, 오염된 장갑에 의한 접촉으로, 치과
진료 도중 환자 입 안에 들어갔던 오염된 기구나 재료에 의해서 등의 다양한 방법으로 오염될 수 있으며, 이러한 오염은 잠재적인 감염의 전파 경로로 작용할 수 있다. ${ }^{19}$ Runnells에 의하면, 손으로 만지거나 액체가 튀는 모든 표면은 멸균을 시행해야 하며, 멸균이 불가능할 경우 적 절한 소독제로 소독을 시행해야 한다고 하였다. ${ }^{20}$ 대부분 의 치과에서 공통적으로 사용되고 있어서 선택된 5종의 기구는 모두 동일 기구 안에 환자의 점막과 접촉하는 부 위가 있는 기구들의 손잡이(인상용 건, 광중합기, 3-way syringe) 혹은 환자의 점막과 접촉하는 기구들의 수납함 (색조 견본, 치실통)부위로, 상대적으로 감염 관리의 필 요성을 인지하지 못하는 부위가 연구 대상으로 선택되었 다. 해당 기구들의 감염 관리에 관한 술자의 인지도를 설 문으로 조사하고, 감염 관리 실태를 해당 기구들의 표면 오염도 측정으로 조사하여 치과 진료실에서 비위험 기구 의 감염 관리에 대한 치과의사들의 인지도와 실태를 연 구하였다.

표면 오염도를 측정하기 위해서 사용된 ATP 측정기 는 검체 채취를 할 수 있는 Ultrasnap ${ }^{\mathrm{TM}}$ ATP swab $(\mathrm{Hy}$ giena LLC)을 이용하여 검사 표면의 ATP 수준을 측정 한다. 제조사의 지시에 따라 검사하려는 표면을 swab으 로 문지른 후 측정 swab에 포함된 촉매제와 반응시키 면 촉매제에 포함된 luciferase와 luciferin에 의해 다음 과 같은 반응이 일어난다: luciferase + D-luciferin $+\mathrm{O}_{2}$ $+\mathrm{ATP} \rightarrow$ luciferase + oxyluciferin $+\mathrm{CO}_{2}+\mathrm{AMP}+$ PPi(inorganic pyrophosphate) + light. $^{21}$ 이 때 발생되는 빛을 ATP 측정기에서 검출하여 RLU 값으로 표시한다. $\mathrm{RLU}$ 값이 높을수록 표면의 ATP가 많다는 뜻으로, 표면 의 유기물 오염도가 높다는 의미를 지닌다. RLU 값은 표 면 미생물 검사를 통한 세균 집락수 계산 값과는 직접적 
인 관계가 없으나, 표면의 미생물 뿐 아니라 ATP를 사용 하는 모든 세포와 유기물이 검출되므로 더욱 보수적인 위생검사가 가능하며, 검사 결과의 재현성이 있어 다양한 분야의 표면 위생 검사에 널리 사용된다. 22,23 제조사의 지 시에 의하면 $10 \times 10 \mathrm{~cm}$ 의 면적을 검사하는 것이 추천되 나, 연구 대상인 기구들의 크기와 형태로 인해 넓은 면적 을 검사하는 것이 불가능하여 기존 연구의 방법을 참고 하여 단위 면적당 RLU 값을 계산하여 통계적 분석에 이 용하였다. ${ }^{24,25}$

기구 표면 오염도를 측정한 결과, 3-way syringe의 손 잡이와 색조 견본의 측정값이 다른 3종의 측정값보다 유 의하게 낮은 값을 나타내었고, 감염 관리 인지도에 관 한 설문과 오염도 측정값과의 상관관계 분석 및 실천도 에 관한 설문과 측정값과의 상관관계 분석에서는 둘 다 3-way syringe만이 음의 상관관계가 있음을 나타내었 다. 실험에 참가한 치과의사들이 다른 기구들과는 달리 3-way syringe는 감염 관리의 필요성에 대해 인식하고 있 고, 높은 빈도로 감염 관리를 실천하고 있으며, 표면 오염 도가 낮게 관리되고 있음을 추정할 수 있다. 이는 다른 4 종의 기구들보다 3-way syringe의 사용 빈도가 높기 때문 으로 추정된다.

3-way syringe의 손잡이와 같이 유니트 체어에 연결되 어 멸균 소독이 어려운 비위험 기구에 적합한 감염 관리 방법은 표면 소독이다. 연구 대상자들이 감염 관리에 사 용하는 방법들 중 3-way syringe는 $77.5 \%$ 가 표면 소독 을 시행한다고 응답함으로써, 5 종의 기구들 중 가장 높 은 비율로 적합한 감염 관리 방법이 시행되고 있음이 나 타났다. 그러나 7명(17.5\%)이 고압증기멸균을 시행한다 고 응답하였으며, 이는 응답자들이 해당 문항을 3-way syringe의 팁(tip)에 관한 문항으로 착오를 일으킨 것으로 보이며, 이는 본 연구의 분명한 한계점 중 하나로 볼 수 있다. 3-way syringe의 팁은 환자의 점막과 접촉하는 준 위험 기구에 속하며, 멸균 혹은 일회용품 사용 후 폐기하 는 방법으로 감염 관리를 시행해야 한다.

색조 견본은 인지도 및 실천도와 표면 오염도 간의 상 관관계는 없었으나 가장 낮은 오염도를 나타내었다. 술 자들의 인지도와 무관하게 낮은 오염도를 나타낸 것은 색조 견본이 다른 기구들보다 상대적으로 사용 빈도가 낮고, 색조 결정과정은 구강내에서 보철 술식을 시행하 기 전에 이루어지기 때문에 오염이 적은 것으로 사료된 다.

인상용 건, 광중합기, 치실통은 인지도 및 실천도와 표
면 오염도간의 상관관계가 나타나지 않았으며, 표면 오 염도는 다른 두 기구들보다 높게 나타났다. 인상용 건은 제조사에 따라 고압증기멸균이 가능한 경우가 있으나, 많은 경우 사용자들은 적절한 감염 관리 방법을 잘 알지 못한다는 연구 결과가 있다. ${ }^{26}$ 광중합기는 기기 고장의 우려가 있으므로 표면 소독이 적합한 감염 관리 방법이 다. 또한 인상용 건과 광중합기의 손잡이 부위는 세 기구 와는 달리 표면 덮개의 사용이 적합한 기구임에도 불구 하고, ${ }^{26}$ 응답자 중 표면 덮개를 사용한다고 응답한 사람 은 광중합기에서의 1 명 뿐인 것로 나타났다.

본 연구의 결과에 따르면 연구에 참가한 치과의사들이 가장 감염 관리의 필요성을 느꼈던 기구인 3-way syringe 는 인지도 및 빈도와 오염도 간의 상관관계가 있었으며, 또한 인지도 및 빈도와 오염도간에는 음의 상관관계가 있었으므로, 이는 감염 관리에 대한 사용자의 인지도 및 빈도가 높다고 응답할수록 표면 오염도가 낮게 측정되었 다는 것을 의미한다. 또한 설문 중 감염 관리를 시행하지 않는 이유에 대한 항목에서 ‘필요성을 느끼지 못함’이 23 개(57.5\%)로 가장 높았다. 이 항목의 결과를 감염 관리 의 필요성에 대한 인지도가 높은 기구가 낮은 오염도를 나타내었다는 통계적 분석 결과와 함께 고려할 때, 추후 감염 관리의 수준을 증진시키기 위해서는 감염 관리 필 요성에 대한 인식을 제고하는 것이 중요하다고 볼 수 있 다. 치과의사들의 감염 관리에 대한 인식을 높이고, 올바 른 감염 관리 방법에 대한 교육이 이루어져야 할 것이다. 또한 감염 관리가 잘 이루어지지 않는 이유에 대한 항목 에서 '과도한 업무량'이 22개(55\%)로 두 번째로 높은 응 답비율을 나타낸 점에서, 임상에서의 현실적인 감염 관리 실천을 뒷받침할 수 있는 제도적 지원의 마련 역시 필요 한 것으로 볼 수 있다.

본 연구의 제한점은 연구 대상자의 표본이 일부 지방 에 한정되어 있고, 그 수가 적어 연구 결과를 일반화 하는 데 한계가 있다는 점이다. 이에 관한 추가적인 연구가 필 요할 것이다. 또한 오염도 측정에서 ATP 측정기로 측정 한 RLU 값을 사용하였으나, 치과 기구의 오염도 측정에 $\mathrm{RLU}$ 값이 명확한 기준점이 없으므로 본 연구의 측정 수 치가 절대적 기준에 비해 높은지, 낮은지를 비교하기가 불가능하였고, 실태 조사는 각 기구 간 표면 오염도 비교 에 그쳤다. 추후의 추가적인 연구에서는 표면 오염도에 대한 기준이 있는 측정법을 사용한다면 더 명확한 기준 이 있는 실태조사가 이루어질 수 있을 것이라 사료된다. 


\section{결론}

치과 치료에 사용되는 비위험 기구의 감염 관리에 대한 인지도 및 실태를 조사하고자 40 개의 치과 병, 의원을 대 상으로 치과의사에게 설문을 시행하고, 진료에 사용하고 있는 비위험 기구 5 종을 대상으로 표면 오염도를 측정하 였다. 이에 본 연구의 한계 내에서 다음과 같은 결론을 얻 었다.

1. 감염 관리에 관한 인지도는 3-way syringe, 광중합 기, 색조 견본, 인상용 건, 치실통 순으로 높았고, 감 염 관리의 빈도는 3-way syringe, 색조 견본, 광중합 기, 인상용 건, 치실통 순으로 높았다.

2. 표면 오염도는 3-way syringe, 색조 견본이 인상용 건, 광중합기, 치실통보다 낮았다.

3. 3-way syringe는 치과의사의 감염 관리에 대한 인지 도와 표면 오염도 간에 유의한 상관관계가 있으며, 인지도가 높을수록 오염도가 낮은 것으로 나타났다.

\section{Acknowledgements}

이 논문은 2018년 원광대학교 교내 지원에 의해 수행 되었음.

\section{ORCID}

Jae Hyun Kim https://orcid.org/0000-0001-9924-319X

Jin-Han Lee https://orcid.org/0000-0001-9360-0635

\section{References}

1. Korea Centers for Disease Control \& Prevention (KCDC). Guidelines for prevention and control of healthcare associated infections, 2017. Available from: http://www.cdc.go.kr/CDC/together/ CdcKrTogether0302.jsp? menuIds=HOME006NU2804-NU3027-MNU2979\&fid $=10713 \& q_{-}$ type $=\&$ q_value $=\& c i d=138061 \&$ pageNum $=1$ (updated 2019 Mar 4).

2. Bolyard EA, Tablan OC, Williams WW, Pearson ML, Shapiro CN, Deitchmann SD. Guideline for infection control in healthcare personnel, 1998. Hospital Infection Control Practices Advisory Committee. Infect Control Hosp Epidemiol 1998;
19:407-63.

3. Lee JH. The infection control of dental impressions. J Dent Rehabil Appl Sci 2013;29:183-93.

4. KOSIS (Korean Statistical Information Service). 2018 Statistics on the aged. Available from: http:// kosis.kr/publication/publicationWord.do (updated 2019 Mar 4).

5. Meskin L, Berg R. Impact of older adults on private dental practices, 1988-1998. J Am Dent Assoc 2000;131:1188-95.

6. Younai FS. Health care-associated transmission of hepatitis B \& C viruses in dental care (dentistry). Clin Liver Dis 2010;14:93-104.

7. Spaulding EH. Chemical disinfection of medical and surgical materials. In: Lawrence C, Block SS, editors. Disinfection, sterilization and preservation. Philadelphia; Lea \& Febiger; 1968. p. 517-31.

8. American Dental Association Council (ADA). Infection control recommendations for the dental office and the dental laboratory. J Am Dent Assoc 1996;127:672-80.

9. Centers for Disease Control (CDC). Guidelines for infection control in dental health-care settings. MMWR (Morb Mortal Wkly Rep) 2003;52:1-61.

10. Kim HK, Lee SJ. The control of transmissible disease in dental practice in Seoul, Korea. J Korean Dent Assoc 1995;33:291-6.

11. Lee YA, Jo MJ, Bae JY, Park HS. A study on practice of infection control among dental staffs in dental office. J Dent Hyg Sci 2007;7:263-9.

12. Kim KM, Jung JY, Hwang YS. A study on the state of infection control in dental clinic. J Korean Acad Dental Hygiene Education 2007;7:213-30.

13. Jeon HS, Lee JH. The study of awareness and practice of infection control on dental practitioners during the prosthodontic treatment. J Korean Acad Prosthodont 2015;53:189-97.

14. Kim K. Likert scale. Korean J Fam Med 2011;32:12.

15. Goebel WM. Reliability of the medical history in identifying patients likely to place dentists at an increased hepatitis risk. J Am Dent Assoc 1979;98: 907-13.

16. Centers for Disease Control (CDC). Recommendations for prevention of HIV transmission in 
healthcare settings. MMWR (Morb Mortal Wkly Rep) 1987;36:1-18.

17. Garner JS, Favero MS. CDC guideline for handwashing and hospital environmental control, 1985. Infect Control 1986;7:231-43.

18. Korean Dental Association (KDA). Infection control procedure in dental office. Available from: https://www.kda.or.kr/downLoad. kda?attach_key $=5156 \&$ save_attach_name $=$ 201605251464143729427021.pdf (updated 2019 Mar 4).

19. Cha SR, Kim KJ. Protocol for disinfection and sterilization in dental clinic. J Korean Dent Assoc 2013;51:130-7.

20. Runnells RR. An overview of infection control in dental practice. J Prosthet Dent 1988;59:625-9.

21. Boyce JM, Havill NL, Dumigan DG, Golebiewski M, Balogun O, Rizvani R. Monitoring the effectiveness of hospital cleaning practices by use of an adenosine triphosphate bioluminescence assay. Infect Control Hosp Epidemiol 2009;30:678-84.
22. Hygiena LLC. SystemSURE Operators Manual V3.0. 2013. Available from: https://www.hygiena. $\mathrm{com} /$ food-and-beverage-products/systemsure. html\# resources (updated 2019 Mar 4).

23. Davidson CA, Griffith CJ, Peters AC, Fielding LM. Evaluation of two methods for monitoring surface cleanliness-ATP bioluminescence and traditional hygiene swabbing. Luminescence 1999;14:33-8.

24. Smith PW, Gibbs S, Sayles H, Hewlett A, Rupp $\mathrm{ME}$, Iwen PC. Observations on hospital room contamination testing. Healthc Infect 2013;18:10-3.

25. Huang YS, Chen YC, Chen ML, Cheng A, Hung IC, Wang JT, Sheng WH, Chang SC. Comparing visual inspection, aerobic colony counts, and adenosine triphosphate bioluminescence assay for evaluating surface cleanliness at a medical center. Am J Infect Control 2015;43:882-6.

26. Westergard EJ, Romito LM, Kowolik MJ, Palenik CJ. Controlling bacterial contamination of dental impression guns. J Am Dent Assoc 2011;142:126974. 


\section{치과 치료에 사용되는 비위험 기구의 감염 관리 실태 조사}

\section{김재현, 이진한*}

원광대학교 치과대학 치과보철학교실

목적: 치과 치료에 사용되는 일부 비위험 기구들에 대한 치과의사의 감염 관리 인지도와 감염 관리 실태를 조사하고자 하였다.

연구 재료 및 방법: 대전광역시, 충청남도, 충청북도 및 전라북도 지역의 40 개 치과 병, 의원을 연구 대상으로 하였다. 감 염 관리에 대한 치과의사의 인지도와 실천정도에 관해서 설문 조사를 시행하였고, 연구 대상인 치과의사가 치과 치료에 사용하는 인상용 건, 광중합기, 3-way syringe, 색조 견본, 치실통의 표면 오염도를 아데노신 3인산 측정기를 이용하여 측 정하였고, 감염 관리에 대한 인식도와 실태 간의 상관관계를 분석하였다.

결과: 감염 관리에 관한 인지도와 시행 빈도는 3-way syringe에서 가장 높았다. 모든 기구에서 소독액을 사용한 표면 소 독이 가장 많이 시행되었다. 표면 오염도는 3-way syringe, 색조 견본이 인상용 건, 광중합기, 치실통보다 낮게 나타났다.

결론: 치과 치료에 사용되는 비위험 기구들 중에서 3-way syringe는 사용자의 감염 관리 인지도와 표면 오염도 간에 유의 한 상관관계가 있으며, 감염 관리의 인지도가 높을수록 표면 오염도가 낮은 것으로 나타났다.

(구강회복응용과학지 2019;35(1):27-36)

주요어: 감염 관리; 치과 기구; 비위험 기구; 표면 오염도 